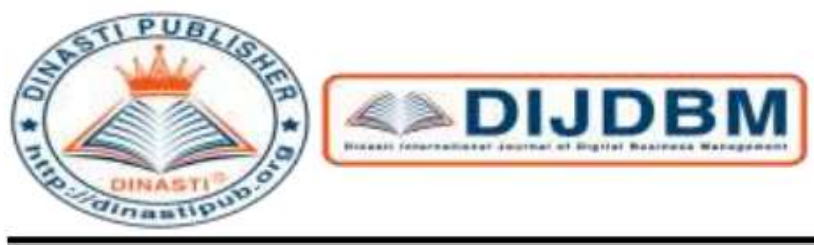

+6281387654578

+628138765 4578

https://dinastipub.org/DIJDBM editor@dinastipub.org

\title{
EFFECT OF ASSOCIATION BRAND, QUALITY PRODUCTS / SERVICES AND PROMOTION OF AWARENESS THROUGH MUSLIM HALAL CONSUMER CONFIDENCE BRAND J.CO DONUTS AND Breadtalk
}

\section{Muhammad Aria Wahyudi}

Postgraduate Doctoral Program, Universitas YAI Persada Indonesia, Jakarta.

\begin{tabular}{|c|c|}
\hline $\begin{array}{l}\text { ARTICLE INFORMATION } \\
\text { Received: } 1 \text { February } 2020 \\
\text { Revised: } 15 \text { February } 2020 \\
\text { Issued: } 20 \text { February } 2020 \\
\text { (filled in by Editor) } \\
\text { E-mail: } \\
\text { arialwahyudi@gmail.com }\end{array}$ & $\begin{array}{l}\text { Abstract: Along with the growing Muslim population } \\
\text { in Indonesia has increased the potential for halal } \\
\text { products were great, the context of the recognition of } \\
\text { halal food needs to be examined further. Halal products } \\
\text { should be recognized as a symbol of cleanliness, safety, } \\
\text { and high quality for Muslim consumers (Merican, } \\
\text { 1995). Until now though there is plenty of halal food } \\
\text { and many research reports about the halal food market, } \\
\text { but the study of the theory of purchasing kosher food is } \\
\text { very rare (Natural \& Suyuti, 2011). To boost economic } \\
\text { growth through the development of halal products, it } \\
\text { must know the level of awareness in Indonesia Muslim } \\
\text { behavior as consumers of halal products. Awareness is } \\
\text { the ability to perceive an event as well as the object, } \\
\text { which implies the concept of understanding and } \\
\text { perception of the event or subject. In a promotional } \\
\text { message to shape perceptions and consumer } \\
\text { confidence, the promotional messages tailored to the } \\
\text { intended target market and the moment or timing. The } \\
\text { brand promotion that is directed to the target market } \\
\text { will very influence awareness Muslim Halal consumer } \\
\text { perception of the brand or the product. Hereinafter } \\
\text { Process author, execute collection primary data related } \\
\text { to Halal Awareness and Brand Trust for Muslim } \\
\text { respondents younger age (18 years to } 35 \text { years), with a } \\
\text { predominance of middle class living in Jakarta and } \\
\text { surrounding areas. This initial survey for identifying } \\
\text { problems Halal Awareness and Brand Trust of } 70 \\
\text { respondents then customized promotional messages to } \\
\text { the intended target market and the moment or timing. } \\
\text { Keywords: Promotions, Kosher Products, Awareness, } \\
\text { Confidence In The Brand. }\end{array}$ \\
\hline
\end{tabular}




\section{INTRODUCTION}

The Government of Indonesia is one of the government with a majority Muslim population in the world. This amount is based on the research results of The Pew Forum on Religion \& Public Life which states that the 10 countries with a Muslim majority for the year 2010 are as follows: 1 Indonesia occupies the first number with a population of 205 million inhabitants, followed Pakistan's 178 million people, India 177 million soul, Bangladesh 149 million, Egypt of 80 million people, Nigeria's 76 million people, Iran and Turkey 75 million, Algeria 35 million, and the latter Morocco with a population of 32 million inhabitants of religion Islam (Reuters, 2015) .

Based on the results of the survey are expected to principles of Islam could give an effect on the formation of mindset and culture in Indonesia. Islam teaches that human beings live their lives correctly, as has been arranged by God. The attempt to live and live properly is what makes a person's life valuable. Good bad real life is not measured by other indicators, but on the extent to which human beings cling to the truth. For that, people need guidance about the truth of life, religion (Williams \& Zinkin, 2010).

The critical attitude of consumers and the kosher community contributed to the growing number of companies doing a certificate this year. He explained that in 2014 there was 10 top product category that is certified kosher. Ranked first are the flavor, seasoning, and fragrance as much as 58320. Furthermore, oil, fat and processed Products (oils, fats and other dairy products) as many as 17 676, restaurant (restaurant) as many as 13 058, noodles, pasta and processed products (noodles, pasta and dairy products) as many as 10268 and a snack (snack) of 9581. The added volume of halal-certified products encourages the basic assumption that Muslims are more aware of the importance of halal food that does not directly lead to the expansion of the global halal food industry (Dasuqkhi, Sirajuddin, Sahri, \& Khalid, 2013).

J.Co Donuts \& Coffee is one of the most frequently visited by the people of Indonesia. In addition to the quality of good taste, J.Co has advantages as 6 pioneer manufacturer of a donut is the concept of the open kitchen, which allows consumers to see the donut-making process from the beginning to be served. Since its inception the J.Co Donuts \& Coffee in the year 2005, the company owned by Johnny Andrean open 79 stores per 2014 both at home and abroad. The high number of outlets showed a high number of applicants this J.Co product which incidentally status is still doubtful because it has no Zertifikat halal by the MUI. It is certainly contrary if the fact that Indonesia is the country with the largest Muslim population in the world, which avoids doubtful products.

Here in after Process author, execute collection primary data related to Halal Awareness and Brand Trust for Muslim respondents younger age (18 years to 35 years), with a predominance of middle class living in Jakarta and surrounding areas. This initial survey for identifying problems Halal Awareness and Brand Trust of 70 respondents in the survey, 56\% of women and $44 \%$ men. Age respondent prioritized $41 \%$ aged 18 years and older diploma educated about $78 \%, 70 \%$ work student/student/I with spending per month on the dominance of $44 \%$ between Rp. 1,000,000 - Rp. 3,000,000. 
This study using a Likert scale, meaning or definition Likert Scale is a scale used to measure the perceptions, attitudes, or opinions about a person or group events or social phenomena, based on the operational definite set by the researchers.

By the theory of a Likert scale, the writer formulated from scores obtained from this initial study. Almost all respondents have doubts about all halal product consumption. This doubt in checking the packaging of halal products purchased at 59\%, hesitant in distinguishing $53.8 \%$ halal label, check the halal certificate number on the product purchased $46 \%$ and confidence halal label on the product package without checking on the website of $54.4 \%$. While knowing the MUI as a bookmark label declared halal products $63.4 \%$.

Promotion role also influences the awareness of Halal brand products. Definition promotion according to Kotler and Armstrong (2012: 76), "Promotion means activities that be communication the merits of the product and persuade the target customers to buy it", that is to say, promotion is an activity that communicates the benefits of a product and persuades target consumers to buy products .

\section{LITERATURE REVIEW}

\section{Halal Awareness}

Awareness is the concept of implies the understanding and perception of the event or subject (Aziz \& Vui, 2013). According to Ahmad, Abaidah, and Yahya (2013) note halal awareness to understand whether or not a Muslim based on what is halal, knowing the correct slaughtering process, and prioritize their kosher food for consumption. According Ambali (2014) in the context of halal consciousness is said to be a process of informing the Muslims to raise the level of awareness of Muslims against what is allowed for food and beverages to be consumed in everyday life (Ambali \& Bakar, 2014)

Based on the understanding of consciousness kosher above, we conclude that the halal consciousness is a process of understanding or knowledge about a Muslim about the halal and kosher way of processing products under the provisions of Islamic law.

\section{Dimensions Halal Awareness}

Dimensions awareness is twofold Awareness Halal Awareness Intrinsic and Extrinsic. Talking about the concept of halal, no approach about a religion which has a greater influence on the empirical study of religion than the concept of Gordon W. Allport. (Allport, 1950) divides the two kinds of religiosity, intrinsic and extrinsic. First, the intrinsic meaning of religious ways that incorporate religious values into him. Values and religion deep into the soul of the believer. Internalizing their religious-spiritual values. Not only the practice of ritual worship without meaning. All worship that influences the everyday attitude. (Donahue, 1985) reviewing the concept of diversity Allport and found that intrinsic religiosity in respect of all life, not prejudiced, intolerant and integrative (Butt, Rose, Wilkins, \& Ul Haq, 2017).

Intrinsic Halal awareness, kosher consciousness that brings people in the dimensions of faith. This dimension contains hope that anyone who religiously sticking to a particular theological view, admit the truth of doctrine - the doctrine. People who have an intrinsic halal awareness, they make sure what she eats is kosher. They do this because of their belief that kosher food is the best food may be consumed by Muslims. People with a high intrinsic 
awareness willing to take the time to understand the concept of halal according to Islam. In consuming the food, they do not quite see what it looks visually (halal logo, composition, etc.), because sometimes there are some food companies are labeled kosher without certification from MUI institutions. Research (Ardyanti et al, 2013), entitled A Study on Muslim Halal Food Awareness Among Customers in Klang Valley showed that consumer awareness of the Muslim halal food is influenced by his understanding of the concept of Halal. Kosher intrinsic human consciousness brings in the dimension of religion (Nurhayati \& Hendar, 2019) .

Extrinsic Halal Awareness (Allport and Ross, 1967) describes the diversity of extrinsic encourage someone to take advantage of his religion. Religion is used so that she gained from her status. Extrinsic religiosity brings the human dimension of religious practice, this dimension includes behaviors worship, observance, and the things that people do to demonstrate a commitment to religion. People who have an awareness of halal extrinsic likely to see something of what was visible. In foods, they tend to pay attention to particulars showing that the food is halal, halal logo eg, composition, etc. By seeing their halal logo, they believe that what is consumed is correct. What it does is because they want to demonstrate a commitment to the religion. (Khalek et al, 2014) in a study entitled Young Consumers Attitude towardHalal Food Outlet and JAKIM 's Halal Certification in Malaysia indicates a positive attitude towards the Muslim youth and certification of halal food outlets JAKIM. Jakim Malaysia is the official agency in charge of the halal certificate, such as the MUI in Indonesia. Research (Masitoh et al, 2013), entitled Perception Toward Halal Awareness and Its Correlation with Halal Certification among Muslims found a positive relationship between consciousness lawful and moderate respondents with their perceptions of the halal certificate. Jakim Malaysia is the official agency in charge of the halal certificate, such as the MUI in Indonesia. Research (Masitoh et al, 2013), entitled Perception Toward Halal Awareness and Its Correlation with Halal Certification among Muslims found a positive relationship between consciousness lawful and moderate respondents with their perceptions of the halal certificate. Jakim Malaysia is the official agency in charge of the halal certificate, such as the MUI in Indonesia. Research (Masitoh et al, 2013), entitled Perception Toward Halal Awareness and Its Correlation with Halal Certification among Muslims found a positive relationship between consciousness lawful and moderate respondents with their perceptions of the halal certificate (Salman \& KAMRAN SIDDIQUI, 2011) .

Based on the above understanding can be concluded that legal awareness is a combination of intrinsic awareness (understanding in detail the concept of halal according to Islam) and awareness extrinsic (likely to see something of what it looks). It can be interpreted awareness of Halal is an understanding of the Muslims against the concept of halal, kosher processes, and principles that ultimately prioritize kosher eating kosher for their consumption. A better understanding of the concept of halal, kosher principles of the process as well as Muslims tends to be more selective in choosing the products they consume.

\section{Halal Certification}

According to Nurcahyo and Hudransyah (2017), kosher certification is a guarantee of security for Muslims to be able to consume the food products according to the teachings of 
Muslims. MUI fatwa which stated about the product by the Islamic Shari'ah also called halal certification. Halal certification is a requirement for obtaining halal labeling on the packaging of the product from government authorities stated by the Indonesian Halal Product Directory (DPHI, 2011). Halal certification also signifies a detailed examination of the process of halal products is ultimately decided in the form of MUI halal status. Products that have passed the test by the MUI halal certification can be evidenced by the halal logo listed in the product packaging (Mujiono, 2016).

\section{Brand Trust}

Confidence in the brand is the perception of the reliability of a consumer standpoint is based on experience, or rather on the sequence of transactions or interactions which are characterized by the fulfillment of the hope of product performance and satisfaction (Research Costabile in Ferinnadewi, 2008). Confidence awakened by the hope that the other party will act by the needs and desires of consumers. In addition, according to Delgado (in Ferrinnadewi, 2008), brand trust is the ability of a brand to be trusted (brand reliability), which is based on consumer confidence that the products are able to meet the promised values and intentions of both brands (brand intention) which is based on consumer confidence that the brand is able to put the interests of consumers (Şahin, Zehir, \& Kitapçi, 2011).

According to Kustini (2011: 23), brand trust can be measured via the dimensions of viability (dimension of viability) and dimensions of intentionality (dimension of intentionality). (1). The dimension of Viability These dimensions represent a perception that a brand can meet and satisfy consumer needs and values. These dimensions can be measured through indicators of satisfaction and value (value). (2). The dimension of intentionality this dimension reflects the feeling of safety of an individual to a brand. These dimensions can be measured through indicators of security and trust (Sung \& Kim, 2010).

\section{Dimensions Brand Trust}

According to Lau and Lee (in Rianna 2008), three factors affect trust in the brand. These three factors are related to the three entities included in the relationship between brands and consumers. As for the third factor is the brand itself, the manufacturer of the brand and the consumer. The relationship of these three factors with confidence in the brand which is also a measuring tool brand trust is (1) Brand Characteristic, (2) Company Characteristic, (3) Consumer Characteristic brand (Sung \& Kim, 2010).

\section{Indicator Brand Trust}

According to Delgado (2001), two indicator variables affect confidence in the brand (brand trust).("Building Brand Loyalty Through Increasing Brand Trust And Brand Affect," 2015)

1) Brand Reliability: is the brand reliability that originates in consumer confidence that the products can meet the promised value or in other words the perception that the brand can meet the needs and satisfaction. Brand reliability is essential for the creation of trust in the brand because the brand's ability meets its promised value will make 
consumers put flavor is sure to get what is needed in this case the need to get out of a feeling of endangerment.

2) Brand Intentions or interest in the brand reflected consumer confidence that the brand can prioritize the interests of consumers when problems in the consumption of the product appear unexpectedly. Therefore, intentionality related to trust that the brand would be interested in what consumers need and will not take advantage of consumer ignorance.

\section{Brand Asosiacion}

According to Chen (research Albari, 2005: 199), brand associations can be divided into product associations and organization associations. Association functional attributes of products in the form of associations, such as product attributes, perceived quality, and functional benefits; as well as non-functional attributes, such as symbolic associations, emotional, price/value, pekai / or the user's situation. Association organization dealing in association ability of the company, namely in the form of expertise produce and delivers products, such as employee skills, the result of technological innovation and industry leadership; as well as the association of corporate social responsibility (Severi \& Ling, 2013).

According to Tjiptono (2011: 98) brand association, ie everything that is associated with the memory of the brand. Brand associations closely related to brand image, which is defined as a series of brand associations with a particular meaning. The brand association has a certain power level and will become stronger with increasing consumption experience or exposure to a specific brand.

The fundamental value of a brand is often a set of associations, in other words, the meaning of the brand for the audience. Associations become a foothold in purchase decisions and brand loyalty. According to Simamora (2001), a brand association that creates value for the company and its customers can also be used to help process information, to distinguish/reposition the brand, generate random to buy, creating a positive attitude, provide a foundation.

\section{Quality Products / Services}

According to Kotler (2005: 156) argues that the quality of products/services must be initiated from the consumer's needs and ends on consumer perceptions. In this case, can be concluded that good quality is not only based on perceptions of the provision of services or service but based on the perception of the consumers themselves. While Roesanto (2000: 44) argues that the quality of service refers to the assessments of the customers about the core of this service and the service provider itself or the entire service organization, most people are now beginning to show demand towards service excellence, they are no longer just need a product that quality but they prefer to enjoy the convenience of service. (Yuen \& Chan, 2010).

Quality of products/services can be determined by comparing the perceptions of consumers for services, which they have received/obtained with the actual service they expect/want to attributes of an enterprise service. If the product/service received or felt (perceived quality) as expected, then the quality of products/services perceived as good and 
satisfactory, if the products/services received exceed the expectations of consumers, the quality of the product/service is excellent and the quality perceived. Conversely, if the quality of products/services received lower than expected, the quality of products/services perceived as bad.

\section{Dimensions of Quality of Products / Services}

According to Zeithaml, Berry, and Parasuraman (1998: 38) has made various studies of some types of products/services, and successfully identified and summarized into five dimensions characteristics used by consumers in evaluating the quality of the product. It was concluded that there are five dimensions of product quality, as follows (Van Dyke, 1994):

1) Tangible (tangible).

2) Trust (reliability).

3) Responsiveness (responsiveness).

4) Assurance and certainty (assurance).

5) Empathy (empathy).

By definition according to the experts above, the authors conclude that the quality of products/services is a comparison between the products/services that are perceived consumer (tangible) with the quality of products/services that are expected and control over the level of excellence to meet the desires of consumers (trust/reliability. So the definition quality of products/services can be interpreted as an effort to fulfill the needs and desires of consumers and accuracy of delivery in balancing the expectations of consumers (guarantees and certainty/assurance). then, the author focuses on three indicators of quality of products/services, namely: tangible, confidence and assurance. While the dimensions others are not used for improper use in this study (Van Dyke, 1994).

\section{Promotion}

According to Husein (2002: 35) promotion is the communication of information between buyer and seller or other parties so that these products are known and eventually purchased. From some of the above theory can be deduced that the promotion is communicating activities to provide information to people about the products that will be offered so that consumers are interested in buying products or services offered. Advertising, sales promotion, and public relations is a mass communication tool available to marketers. As the name suggests, mass communication using the same message to everyone in the audience. Many definitions of advertising, where ads are defined as the process of communication, marketing processes, economic and social processes, process information and persuasion (Gamble, Gilmore, Mccartan-Quinn, \& Durkan, 2011).

\section{Campaign Goals}

According to Nickels, et al (2008: 10), the promotion aims to influence people to participate in the purchase. The promotion also aims to motivate the community to buy the products or services of a company, as well as a means to build relationships with major customers. Our sale is modified consumer behavior, informs, influence and persuade and 
remind consumers about the company's objectives and the products or services sold (Mohayidin \& Kamarulzaman, 2014).

\section{Indicators Promotion}

There are several indicators or dimensions to measure Promotion is through the promotion mix is a communication tool that consists of a combination of promotional tools used by the company. so that such can not be separated, because they are mutually supportive and complete (Todorova, 2015) the promotion mix are:
a) Sales-face
b) Advertising
c) promotion selling
d) Publicity public relations

\section{FINDINGS AND DISCUSSION}

\section{Influence of Brand Association Against Brand Trust}

According Outcomes and Lin (2003) in Ferrinadewi (2008: 147) the trust is a number of specific beliefs to integrity (honesty party trust and the ability to keep promises), benevolence (attention and motivation that are believed to act in accordance with the interests of the trust them), competency (the ability of the trust to carry out the needs of the trust) and predictability (behavioral consistency trusted party. from the perspective of consumers, brand trust is a psychological variable that reflects the amount of accumulation of the initial assumptions of association-association involving credibility, integrity, and benevolence which were attached to a particular brand. Trust the brand will affect customer satisfaction and loyalty. A trusted brand has an important role for the brand. If the effect of brand trust is not controlled can lead to the consideration of the level of customer satisfaction excessive interest in developing the consumer's commitment to the product (Kumar, Dash, \& Purwar, 2013) .

According to Keller (in research Yulianti, et al, 2012: 4) brand image is a set of consumer confidence in certain brands. Where the perception of the brand is portrayed by the brand associations stored in the memory. It explains that the brand image is the perception that shapes the minds of consumer confidence.

\section{Against Brand Quality Impact Brand Trust}

Welch in Kotler and Susanto (2002: 69), the quality is the guarantee of customer loyalty, our best defense against rivals from the outside, and the only path to lasting growth and income. The definition of quality according to the American Society for Quality Control is the overall characteristics and properties of the goods and services that affect its ability to meet the needs expressed or implied (Kotler and Susanto, 2002: 72).

Under these conditions, the effect of product quality to very high confidence because it is associated with the consumer confidence that the products can meet the promised value and good intentions brand (brand intention) which is based on consumer confidence that the brand can put the interests of consumers. 


\section{Influence Campaign/Promotion Against Brand Trust}

According to Rangkuti (2010: 50), the promotion is the sales and marketing activities to inform and encourage demand for products, services, and ideas of the company by affecting consumers to purchase the products and services produced by the company.

After looking at the above definition, it can be concluded that the promotion is to communicate or inform activities benefit from products and services to consumers to encourage and persuade consumers to buy products and services. The better the promotion or communication delivered by providing information on the benefits of products/services it will be able to improve also the effect on consumer confidence. (Son et al., 2015). "Trust (trust) is the foundation of the business". Building trust in a long-term relationship with our customers is an important factor in creating customer loyalty. This belief is not simply to be recognized by other parties/business partners, but must be built from scratch and can be substantiated. According to Prasaranphanich (2007: 23).

\section{Influence of Brand Association, Product Quality, and the Campaign Against Brand Trust.}

In principle, any information contained in the brand association connected with the mind of consumers, and reflects the brand image (Keller, 1993; Romaniuk and Sharp, 2003). The higher the brand association in the product, the more that will be remembered by consumers and are loyal to the brand. Previous research by Pouromid and Iranzadeh (2012) showed that the relationship between brand associations and brand equity is positive and significant. The brand association has significantly contributed to the establishment of a brand image. With the above study, the researchers sought to build brand association sizes that can be used in various contexts of goods and services. This will be achieved by directly raises the brand association of consumers in various contexts of goods and services. Several previous studies have used the procedure to generate a list of free-thinking of items to measure brand association (baack, and Waterman, 2011). Keller (1993) and Supphellen (2000) argues that brand association is in the minds of consumers, so the direct depiction of the consumer associations will provide the most accurate measure (Romaniuk \& Sharp, 2003).

According to Feigenbaum (1992: 6), The quality of products is the overall combination of product characteristics of marketing, engineering, production and maintenance which make products used meet the expectations of the customer's expectations. So the quality of products is the number of attributes or properties - properties that descriptive in the product (goods and services) and used to meet expectations - the expectations of customers. The conclusion that can be drawn from some of the above definition is that the quality of a product is the content of the level of the merits of a comprised of all the factors inherent in the goods or services so that the goods have the capability to be used as desired by the consumer to enhance the brand image of these products, Basically an improvement in product quality requires an improvement involving everyone in the company to increase better results. Therefore we need a high-quality product that will continue to increase the brand image.

The role of promotion also affects the confidence of a brand product, meaning the message and media campaign or appropriate communication will positively affect consumer confidence in the brand/product specific. Definition of promotion according to Kotler and Armstrong (2012: 76), "Promotion means activities that be communication the merits of the 
product and persuade the target customers to buy it", that is to say, the promotion is an activity that communicates the benefits of a product and persuades target consumers to buy products (Kiran, Kishore, \& Majumdar, 2012) .

Development of a positive brand association, product or service quality guaranteed or maintained and communicated properly through proper media selection will create and strengthen confidence in the brand itself. Because trust the brand as alleged by the belief in the reliability and intention of a brand in a situation involving the risk for consumers. The belief is the notion or expectation that the brand is reliable to behave generously and responsive to the needs of a person. For companies, confidence in the brand is an important target to achieve. The survival of both the company and the product is highly dependent on consumer confidence (Berens \& Popma, 2014).

\section{Influence of Brand Association Against Halal Awareness}

Awareness describes human perception and cognitive reactions related to what they eat, drink and use. Subjectively, awareness is a relative concept in which a person may be partially aware or may be fully aware of the problems associated with kosher aspects or things what is permitted by Allah SWT. Self-awareness means being aware as an individual with personal thoughts about the state of things related to halal. Therefore, halal awareness can be conceptualized as a process of obtaining information to increase the level of awareness of what is permissible for Muslims to eat, drink, and use (Ayuniyyah, Hafidhuddin, \& Hambari, 2017).

Muslim Consumers tend to choose products that have been declared lawful and the perception is its close association with lawful to late compared to products that have not been declared lawful by the competent authority (LPPOM MUI). That is because food products and cosmetics that have been declared lawful tend to be more secure and protected from harmful substances.

\section{Effect of Awareness Against Product Quality Halal}

Most consumers are very serious to find out what they consume and this information is generally contained in food labeling. In this food labeling generally listed composition or any materials used in making these foods. It also affects consumer awareness of the product. Consumers will see the label composition as knowledge to buy the product or not (Jonah et al, 2013: 148). In Islamic thought, halal food is not just a matter of containing parts of animals that are not kosher to be eaten or used by Muslims. However, certain criteria must be considered such as kosher food also includes aspects of safety and quality are related to the handling, processing, equipment, processing aids, packaging, storage, transportation (Tieman, 2015),

It is thus the product quality and consumer awareness of halal for Muslims that are linked can not be separated. This is because the main component of the quality of the product is to cover all aspects of safety and quality is closely related to the handling, processing, equipment, processing aids, packaging, storage, transportation, distribution and retail in the process is ensured halal. Pay attention to product quality Halal process then certainly the value of your products and services without the slightest deficiency and produce products and services according to consumer expectations requires a Muslim Halal awareness for product consumption. 


\section{Halal Awareness Campaign Against Influence}

Any promotion or brand communications aimed at one of them to get a response to the level of brand awareness that is capable of higher brand recall (recall). Through promotional efforts or effective brand communication and consistent, some brand became very famous and able to be remembered by anyone with a standard level of consciousness. Kotler and Asmtrong that the promotion (marketing communication) is a way that companies use to inform, persuade and remind consumers, either directly or indirectly, on the products and brands they sell (Kotler and Asmtrong, 2004: 496). Shimp (2003: 106) mentions the promotion or marketing communications efforts directed at achieving the goals that one of them is creating brand awareness (brand awareness) (Ataman, Mela, \& Van Heerde, 2008).

Then the halal brand promotion and awareness possessed a strong relationship, promotion directed to Muslim consumers will create the perception that the brand communicated or promote a product or brand is safe for consumption by Muslim consumers. Safe is not necessarily kosher, the Muslim Consumers in choosing halal products very careful - careful, if consumers are convinced that these promotions are conveyed information on halal products or services, then the halal consciousness is formed in the minds of consumers. But not a few consumers have a low Halal awareness, every sale of products or services nuances of Islamic, some perceive that the brand or the product is kosher, although his communication message does not explain the product is halal or not.

\section{Effect of Awareness Against Halal Brand Trust}

According to Delgado (in Ferrinnadewi, 2008), brand trust is the ability of a brand to be trusted (brand reliability), which is based on consumer confidence that the products are able to meet the promised values and intentions of both brands (brand intention) which is based on consumer confidence that the brand able to prioritize the interests of consumers. Costabile (1998) confidence or trust is defined as the perception of the reliability of a consumer standpoint is based on experience, or rather on the sequence of transactions or interactions were characterized by Unfulfilled expectation of product performance and satisfaction (Sandra, 2010).

Halal consciousness is the level of knowledge held by Muslim consumers to find and consume halal products by Islamic law (Shaari and Arifin, 2010). Muslim consciousness characterized by their knowledge of raw materials, packaging products, and hygiene products according to Islamic law. Research conducted by Yunus et al (2014) stated that the Muslim halal awareness significantly influences consumer purchase interest for a product (Yunus, Rashid, Ariffin, \& Rashid, 2014).

It is a very strong related to trust brands with halal awareness. Kompenen important because confidence in the brand is the brand reliability and confidence halal brand awareness is in harmony with the Muslim consumer confidence towards knowledge process, raw materials, packaging products, and hygiene products according to Islamic law. Where the brand's reliability and confidence in the brand should ensure that the brand product lawfully processes to strengthen consumer-brand trust, especially for Muslims (Aziz \& Chok, 2013). 


\section{Influence of Brand Association, Quality Products, Promotion, and Awareness Against} Halal Brand Trust.

According to Iranita (2013: 2) producing halal products is part of corporate responsibility on Muslim consumers. In Indonesia, to assure consumers that the product is consumed is kosher, the company needs to have the MUI halal certificate, on the other hand, Islam also regulates how to determine the positive and honest message in the minds of consumers (Oktavia, Marwa, \& Yulianita, 2019).

Generally it can be indicated that if Muslim consumers have brand association is positive, supported by guaranteed product quality halal and communicated well and honestly about the halal brand or product, then the level of trust that is built up to the brand very well have an impact on an impulse to the awareness of Halal the higher of the brand that is consumed.

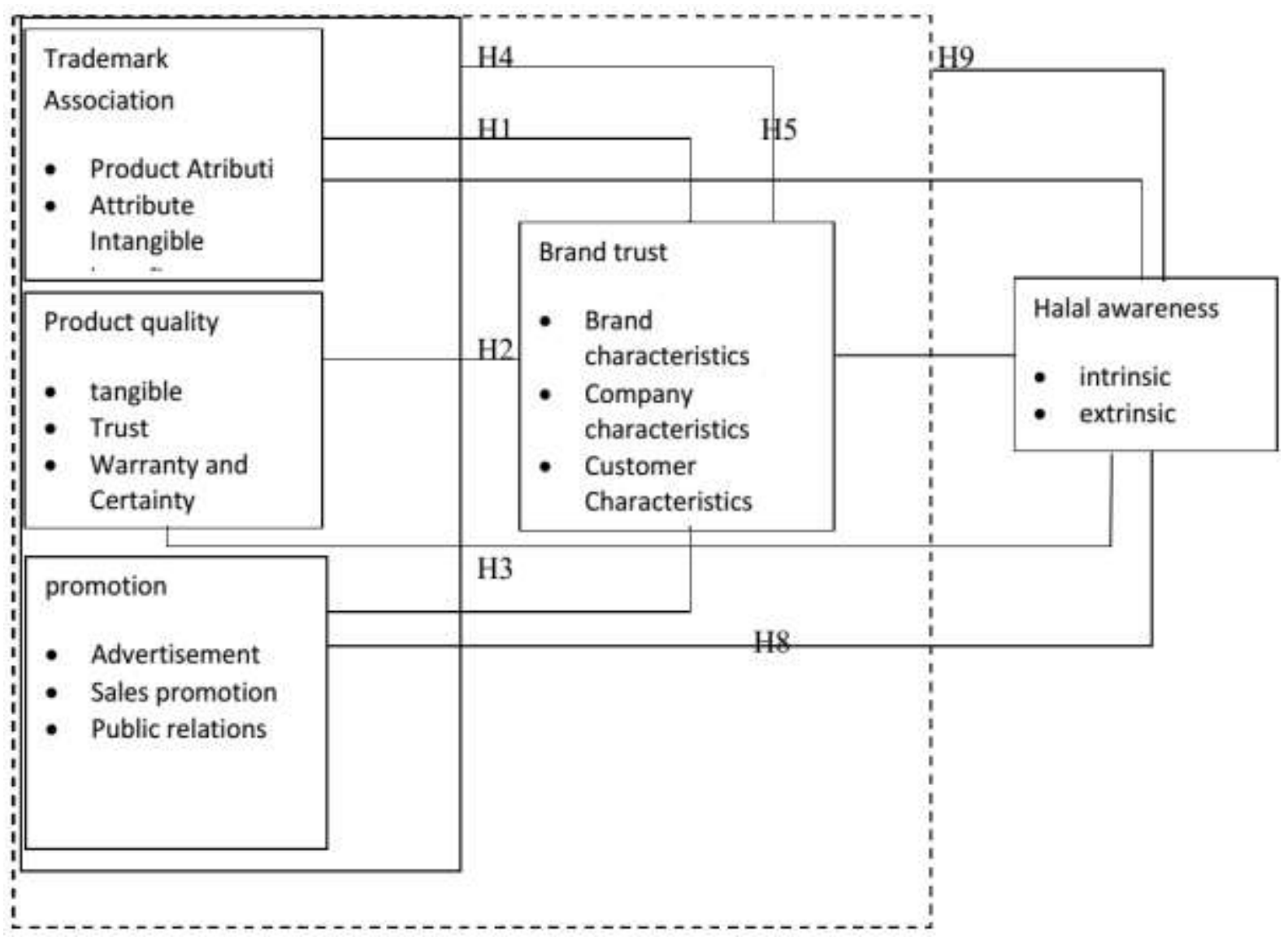

\section{CONCLUSION}

Based on the description of the theory and framework that has been presented above, it can be formulated hypothesis of the study as follows:

1. There is the influence of brand associations on brand trust.

2. There is an influence on the product quality brand trust.

3. There is the influence of promotions on brand trust

4. There aosiasi influence brand, product quality, and promotion together - equal to the confidence in the brand.

5. There is the influence of the brand on the awareness of halal Asosasi

6. There is an impact on the awareness of product quality kosher 
7. There is the effect of promotion of halal awareness

8. There is confidence in the brand influence to the awareness of halal

9. There is the influence of the brand association, product quality, promotion and brand trust together - similar to kosher consciousness.

\section{REFERENCE}

Ambali, A. R., \& Bakar, A. N. (2014). People's Awareness on Halal Foods and Products: Potential Issues for Policy-makers. Procedia - Social and Behavioral Sciences. https://doi.org/10.1016/j.sbspro.2014.01.1104

Ataman, M. B., Mela, C. F., \& Van Heerde, H. J. (2008). Building brands. Marketing Science. https://doi.org/10.1287/mksc. 1080.0358

Ayuniyyah, Q., Hafidhuddin, D., \& Hambari, H. (2017). Factors Affecting Consumers' Decision in Purchasing MUI Halal-Certified Food Products. Tazkia Islamic Finance and Business Review. https://doi.org/10.30993/tifbr.v10i2.111

Aziz, Y. A., \& Chok, N. V. (2013). The Role of Halal Awareness, Halal Certification, and Marketing Components in Determining Halal Purchase Intention Among NonMuslims in Malaysia: A Structural Equation Modeling Approach. Journal of International Food and Agribusiness Marketing. https://doi.org/10.1080/08974438.2013.723997

Berens, G., \& Popma, W. T. (2014). Creating consumer confidence in csr communications. Critical Studies on Corporate Responsibility, Governance and Sustainability. https://doi.org/10.1108/S2043-9059(2014)0000006004

Building Brand Loyalty Through Increasing Brand Trust And Brand Affect. (2015). International Journal of Scientific \& Technology Research.

Butt, M. M., Rose, S., Wilkins, S., \& Ul Haq, J. (2017). MNCs and religious influences in global markets: Drivers of consumer-based halal brand equity. International Marketing Review. https://doi.org/10.1108/IMR-12-2015-0277

Dasuqkhi, M., Sirajuddin, M., Sahri, M., \& Khalid, M. M. (2013). Introducing Halalan Tayyiban Concept in Global Industry Practices: An Innovative Attempt 2 . The Recent Halal Concept. International Proceedings of Economics Development and Research. https://doi.org/10.7763/IPEDR.

Gamble, J., Gilmore, A., Mccartan-Quinn, D., \& Durkan, P. (2011). The Marketing concept in the 21st century: A review of how Marketing has been defined since the 1960s. The Marketing Review. https://doi.org/10.1362/146934711x589444

Kiran, V., Kishore, K., \& Majumdar, M. (2012). Innovation in In-Store Promotions : Effects on Consumer Purchase Decision. European Journal of Business and Management.

Kumar, R. S., Dash, S., \& Purwar, P. C. (2013). The nature and antecedents of brand equity and its dimensions. Marketing Intelligence and Planning. https://doi.org/10.1108/02634501311312044

Mohayidin, M. G., \& Kamarulzaman, N. H. (2014). Consumers' Preferences Toward Attributes of Manufactured Halal Food Products. Journal of International Food and Agribusiness Marketing. https://doi.org/10.1080/08974438.2012.755720 
Mujiono, S. (2016). Perlindungan Konsumen: Labelisasi Halal. Jurnal Ekonomi Dan Bisnis Islam.

Nurhayati, T., \& Hendar, H. (2019). Personal intrinsic religiosity and product knowledge on halal product purchase intention: Role of halal product awareness. Journal of Islamic Marketing. https://doi.org/10.1108/JIMA-11-2018-0220

Oktavia, L., Marwa, T., \& Yulianita, A. (2019). Analysis of Factors Affecting Millennial consumers' Demand for halal Bread Products. MIR (Modernization. Innovation. Research). https://doi.org/10.18184/2079-4665.2019.10.3.395-407

Reuters, T. (2015). State of the GLOBAL ISLAMIC ECONOMY. Dubai the Capital of Islamic Economy.

Romaniuk, J., \& Sharp, B. (2003). Measuring brand perceptions: Testing quantity and quality. Journal of Targeting, Measurement and Analysis for Marketing. https://doi.org/10.1057/palgrave.jt.5740079

Şahin, A., Zehir, C., \& Kitapçi, H. (2011). The effects of brand experiences, trust and satisfaction on building brand loyalty; an empirical research on global brands. Procedia - Social and Behavioral Sciences. https://doi.org/10.1016/j.sbspro.2011.09.143

Salman, F., \& KAMRAN SIDDIQUI. (2011). An exploratory study for measuring consumers awareness and perceptions towards halal food in Pakistan. Interdisciplinary Journal of Contemporary Research in Business.

Sandra, H. dan J. O. H. (2010). Pengaruh Iklan Heritage Terhadap Brand Awareness, Brand Trust dan Intensi Pembelian. Jurnal Manajemen Teori Dan Terapan.

Severi, E., \& Ling, K. C. (2013). The mediating effects of brand association, brand loyalty, brand image and perceived quality on brand equity. Asian Social Science. https://doi.org/10.5539/ass.v9n3p125

Sung, Y., \& Kim, J. (2010). Effects of brand personality on brand trust and brand affect. Psychology and Marketing. https://doi.org/10.1002/mar.20349

Tieman, M. (2015). Halal clusters. Journal of Islamic Marketing. https://doi.org/10.1108/JIMA-05-2014-0034

Todorova, G. (2015). Marketing communication mix. Trakia Journal of Science. https://doi.org/10.15547/tjs.2015.s.01.063

Van Dyke, S. K. (1994). Dimensions of quality. EMJ - Engineering Management Journal. https://doi.org/10.1080/10429247.1994.11414783

Williams, G., \& Zinkin, J. (2010). Islam and CSR: A study of the compatibility between the Tenets of Islam and the UN global compact. Journal of Business Ethics. https://doi.org/10.1007/s10551-009-0097-X

Yuen, E. F. T., \& Chan, S. S. L. (2010). The effect of retail service quality and product quality on customer loyalty. Journal of Database Marketing and Customer Strategy Management. https://doi.org/10.1057/dbm.2010.13

Yunus, N. S. N. M., Rashid, W. E. W., Ariffin, N. M., \& Rashid, N. M. (2014). Muslim's Purchase Intention towards Non-Muslim's Halal Packaged Food Manufacturer. 


Procedia - Social and Behavioral Sciences.

https://doi.org/10.1016/j.sbspro.2014.04.018 